\title{
Electron Tunneling SiGe RTD with Enhanced Current Density Formed Using Quadruple-layer Buffer
}

\author{
Hirotaka Maekawa Non-member, Yoshihiro Sano Non-member, Yoshiyuki Suda, Member (東京農工大学大学院) \\ Chihiro Ueno Non-member (東京農工大学工学部)
}

Keywords : buffer layer, misfit dislocation, resonant tunneling diode, RTD, triple-layer buffer, quadruple-layer buffer

Si/Si1-xGex resonant tunneling diodes (RTD) have been intensively studied as one of next-generation quantum effect devices formed with Si-system materials. Previously, we have applied a combination of electron tunneling and multiple wells using a type II band offset structure, and have reported a high peak-to-valley current ratio (PVCR) of $\sim 8$ at room temperature. In the practical level, PVCR values of $>\sim 10$ and current densities of $>\sim 10 \mathrm{kAcm}^{-2}$ are required for the high frequency oreration.

To obtain type II band offset structure, a structure of strained Si / unstrained SiGe is required on a Si substrate. Previously, we have proposed a triple-layer buffer shown in Fig. 1. We have also experimentally cleared the relaxation mechanisms which are also illustrated in Fig. 1. In the triple-layer buffer formation process, the 1st and 2nd layers are grown coherently. When the 3rd layer is grown, the lattice mismatch of the lower interface between the 2 nd layer and the substrate become larger than that of the upper interface between the $2 \mathrm{nd}$ and the 3 rd layer. Therefore, most misfit dislocations are generated in the lower interface and the 3rd layer relaxes the lower layer and prevents threading dislocations from propagating to the buffer top surface. Thus, we show that our triple layer buffer is effective to form a relaxed buffer with high crystalline surface.

However, when we carry out high $\mathrm{P}$ doping during the buffer and emitter region growth for a vertical-type RTD to increase the current density, the buffer surface crystallinity is degraded because the crystallization is affected by the potential fluctuation induced by $\mathrm{P}$ dopants and the threading dislocations are easily generated.

To solve this problem, we have proposed a quadruple-layer buffer where misfit dislocations are distributed in the lower two interfaces and a higher crystalline buffer surface is obtained. With this buffer, we have successfully fabricated a high current density and high PVCR RTD. In this paper, we report the growth mechanisms of the quadruple-layer buffer and the results of application of this buffer to a conventional vertical-type RTD.

In the quadruple-layer buffer design, we grow the 1 st $\mathrm{Si}_{0.88} \mathrm{Ge}_{0.12}$ layer and the 2 nd $\mathrm{Si}_{0.82} \mathrm{Ge}_{0.18}$ layer, the total thickness of which is under the critical thickness, coherently on $\operatorname{Si}(001)$.

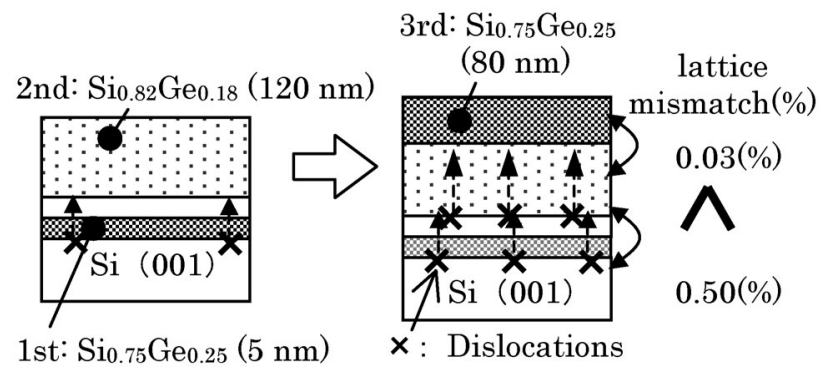

Fig. 1. Relaxation mechanisms of our proposed thin triple-layer buffer

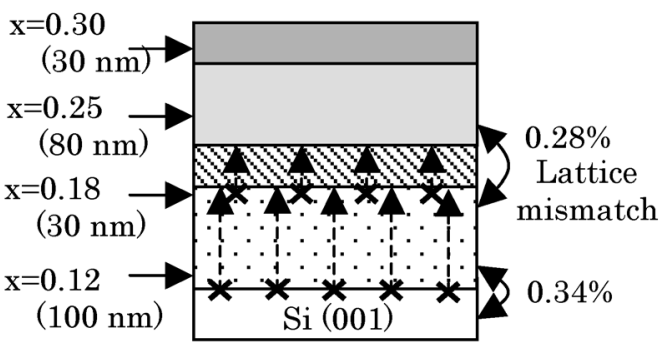

Fig. 2. Structure of a quadruple-layer buffer doped with $P$ and obtained lattice mismatches

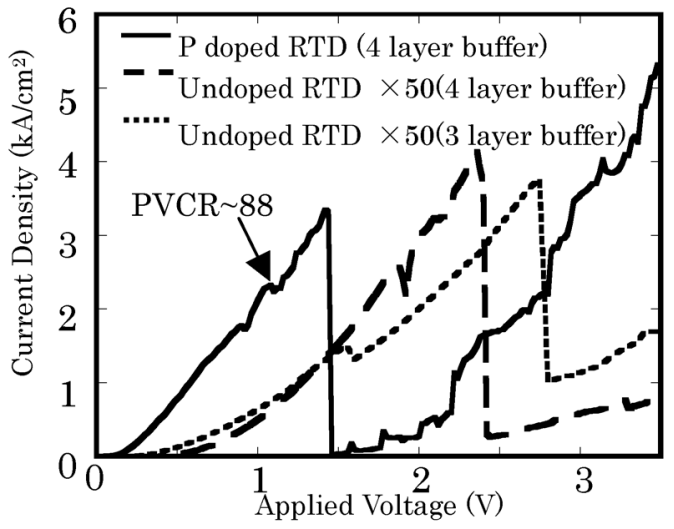

Fig. 3. Comparison between $I-V$ characteristics of RTDs fabricated with the $\mathrm{P}$ doped quadruple-layer buffer and undoped buffer

When the $3 \mathrm{rd} \mathrm{Si}_{0.75} \mathrm{Ge}_{0.25}$ layer and the 4th $\mathrm{Si}_{0.70} \mathrm{Ge}_{0.30}$ layer are grown, the buffer relaxes, however, the threading dislocations do not increase. The lattice mismatches of the lower two interfaces become large as illustrated in Fig. 2. Since the threading dislocations do not increase, the top two layers function to drive generation of misfit dislocations in the lower two interfaces and prevent the threading dislocations from propagating to the buffer top surface. The misfit dislocations are distributed in multiple (two) interfaces and the generation of threading dislocations in the two top layers is effectively restrained. Then, the higher surface crystallinity is also obtained even under high $\mathrm{P}$ doping during the buffer growth.

In Fog. 3, typical I-V characteristics are compared between RTDs fabricated using a triple-layer buffer and a quadruple-layer buffer, and between RTDs fabricated with a P-doped quadruple-layer buffer and a nondoped quadruple-layer buffer. With the P-doped quadruple-layer buffer, the buffer surface crystallinity increased and a high current density of $3.4 \mathrm{kAcm}^{-2}$ and a high current PVCR of $\sim 88$ were simultaneously obtained. 


\title{
4 層バッファを用いた高電流密度電子トンネル型 SiGe RTD
}

\author{
非会員 前川 裕隆* 非会員 佐野 嘉洋* \\ 非会員 上野 千尋** 正 員 須田 良幸*
}

\section{Electron Tunneling SiGe RTD with Enhanced Current Density Formed Using Quadruple-layer Buffer}

Hirotaka Maekawa*, Non-member, Yoshihiro Sano*, Non-member, Chihiro Ueno**, Non-member, Yoshiyuki Suda*, Member

We have proposed a strain-relaxed quadruple-layer buffer on the basis of our previously proposed thin doubleand triple-layer formation mechanisms. With the quadruple-layer buffer, we have demonstrated that misfit dislocations are mainly generated and distributed in the two lower interfaces and the third and fourth layers drive the dislocation generation and prevent the dislocations from propagating to the surface. A resonant tunneling diode fabricated with the quadruple-layer buffer exhibits both a high current density and a high peak-to-valley current ratio.

キーワード : バッファ層, 不整合転位, 共鳴トンネルダイオード, 歪緩和, RTD, SiGe

Keywords : buffer layer, misfit dislocation, resonant tunneling diode, RTD, strain relaxation, SiGe

\section{1. はじめに}

共鳴トンネルダイオード（RTD, Resonant Tunneling Diode) は次世代の高速論理素子として期待されている。RTD は量子井戸内の離散準位を利用したスイッチング素子であ り, その $I-V$ 特性は微分負性抵抗 (NDR, Negative Differential Resistance) を示す。RTD の静特性の重要な 性能指標の一つに微分負性領域の電流の山対谷比（PVCR, Peak-to-Valley Current Ratio)があり, その值として, 実用 には 10〜程度が必要とされる。また, 高速動作するために $10 \mathrm{kAcm}^{-2}$ 程度以上の電流密度が必要とされる。

III- V 族系化合物半導体を用いると容易に高い障壁を得る ことができることから主にIII-V族系 RTD の開発が進めら れてきた。これまで，III- V族系化合物半導体の材料の組み 合わせを用いて固体発振素子としては最速の $712 \mathrm{GHz}$ の動 作周波数を示す RTD が報告されている(1)(2)。Si ベースのIV

\footnotetext{
* 東京農工大学大学院 工学教育部 電子情報工学専攻 干184-8588 東京都小金井市中町 2-24-16 Graduate School of Engineering, Engineering, Graduate School of Engineering, Tokyo University of Agriculture and Technology

2-24-16 Naka-Cho Koganei, Tokyo 184-8588, Japan

** 東京農工大学 工学部 電気電子工学科

干184-8588 東京都小金井市中町 2-24-16

Department of Electrical and Electronic Engineering, Faculty of Engineering, Tokyo University of Agriculture and Technology

2-24-16 Naka-Cho Koganei, Tokyo 184-8588, Japan
}

族系 RTD は数百 $\mathrm{GHz}$ から $1 \mathrm{THz}$ の高速動作が期待され(3), 現行 $\mathrm{Si}$ 論理素子との一体集積が可能になるなどの大きな利 点を有するにもかかわらずその動作報告は少ない。これは, $\mathrm{Si} / \mathrm{SiGe} \mathrm{IV}$ 族系混晶半導体を用いた場合, 障壁が低いことが 一因となっている。

Si/SiGe RTD では, キャリアとして正孔および電子のい ずれも用いられている。正孔をキャリアとする場合は, Type I のバンドオフセットを用いた無歪 Si (障壁) /歪 SiGe（井 戸）の構造, Type II のバンドオフセットを用いた歪 Si（障 壁）/無歪 $\mathrm{SiGe}$ (井戸) の構造が用いられる。しかし，これ まで室温でNDR が観測されていない。その要因の一つに, 正孔の有効質量が複数あり井戸内に量子準位が多数形成さ れるため, 熱励起により複数の準位でトンネルが生じて, NDR がブロードになることが指摘されている(4)。

電子をキャリアとする場合は, Type I の構造ではバンド オフセットを得るのが難しいため, Type II のバンドオフセ ットを用いた歪 Si (井戸)/無歪 $\mathrm{SiGe}$ (障壁) の構造が用い られる。歪 Si の伝導带は縮退バンドが分裂し, 走行方向で 単一有効質量となるため, 井戸内の量子準位数が低減する。 我々は理論計算に基づき, 電子トンネルと多重量子井戸の 組み合わせが NDR 特性向上に最も効果があることを見出し, この組み合わせを初めて適用して RTD を試作して PVCR〜 7.6 を得た(5)。

Type II で量子井戸部の無歪 SiGe 層を形成するためには, 
$\mathrm{Si}$ 基板上に歪を緩和するための歪緩和 $\mathrm{SiGe}$ バッファを形成 する必要がある。歪緩和を行うために, SiGe バッファ/Si 基板界面に不整合転位を導入する。この時生じる貫通転位 がバッファ表面に達すると, バッファ表面の結晶性, 平坦 性を悪化し，デバイス特性を悪化する。

従来歪緩和のために, SiGe 組成比を $0.1 \mu \mathrm{m}^{-1}$ の割合で 連続的に変えながら成長して形成する組成傾斜型バッファ が用いられ(6), 貫通転位密度は $10^{6} \mathrm{~cm}^{-2}$ 程度であったが, 膜 厚が厚くなるため, 作成時間が長くなりコストが増大する。 これに対し, 我々は $\mathrm{Ge}$ 組成を段階的に濃くし, 薄化した, 薄化 2 層バッファを提案した ${ }^{(7)}$ 。さらに, より安定した転位 発生位置の制御のために, 高 $\mathrm{Ge}$ 組成の極薄 $\mathrm{SiGe}$ 層を $\mathrm{Si}$ 基板上に挿入した薄化 3 層構造を提案した ${ }^{(8)}$ 。これらバッフ アの層構造は, 下位界面の応力が上位界面より大きくなる ように形成する。このような形成過程で主に下位界面に転 位が生じ，貫通転位の表出を上位層が抑制してバッファ表 面の結晶性が向上する。

しかし, 電流密度を上げるため, 基板を低抵抗化すると, これらのバッファを用いても貫通転位表出の抑制が難しい という問題が生じた。本研究室では, 薄化 2,3 層バッファ 形成技術を基に，さらに，転位発生位置を分散する 4 層バ ッファを導入して, 高 PVCR と高電流密度の特性を同時に 得ることを可能とした。本論文では，はじめに 2 層， 3 層バ ッファについて概観し, 新しい 4 層バッファ技術と, この 4 層バッファを用いて作成した RTD の特性について述べる。

\section{2. 実験}

Si 層, SiGe 層は GS-MBE 法 (Gas Source Molecular Beam Epitaxy）を用い, Si (001) 基板上に形成した。成 膜チャンバーの背圧は 10-10 torr 台で, 試料表面は成膜チャ ンバー内で通電加熱法を用いて $1000^{\circ} \mathrm{C} て ゙$ 清浄化した。 $\mathrm{Si}$,

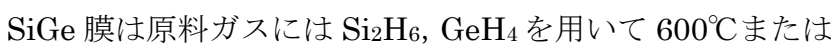
$630^{\circ} \mathrm{C}$ で成長した。また， $\mathrm{n}$ 型ドーピングを行う場合は，ド 一ピングガスとして $\mathrm{H}_{2}$ 希釈した $\mathrm{PH}_{3}$ を用いた。ドーパント 濃度は $10^{19} \mathrm{~cm}^{-3}$ とした。ドーピング後 $800^{\circ} \mathrm{C}, 3$ 分アニー ル処理を施した。作成した試料の歪緩和率を XRD（X-ray Diffraction）の測定結果を用いて評価し，また試料表面の 観察は走查型電子顕微鏡（SEM, Scanning Electron Microscope）を用いて行った。また, SiGe の Ge 組成, P ドープ量は二次イオン質量分析 (SIMS, Secondary Ion Mass Spectrometry）法を用いて評価した。

\section{3. 結果および考察}

〈3・1〉 薄化 2 層, 3 層バッファ ${ }^{(7)(8)}$ これまで提案し た薄化 2 層バッファ, 極薄高濃度 $\mathrm{Ge}$ 組成層を挿入した薄化 3 層バッファの形成原理を Fig. 1 に示す。薄化 2 層バッフ アでは第1層（ $\left.\mathrm{Si}_{0.82} \mathrm{Ge}_{0.18}\right)$ の膜厚を臨界膜厚以下 $(120 \mathrm{~nm})$ とし, 歪を保ったままコヒーレント成長させる。その後, 第 2 層（ $\mathrm{Si}_{0.75} \mathrm{Ge}_{0.25 ）}$ を成長させると歪緩和が生じる。第 2 層の $\mathrm{Ge}$ 組成と厚夕は第 1 層と第 2 層間よりも $\mathrm{Si}$ 基板と第
1 層間の下位界面の応力が高くなるように設定した。成長後, 格子不整合を調べると，下位界面の格子不整合が大きく

$(0.35 \%)$ 上位界面の格子不整合 $(0.08 \%)$ が小さい。また， 表面の貫通転位密度も〜 $10^{5} \mathrm{~cm}^{-2}$ 程度と少ない。したがって， 不整合転位が下位界面に集中的に発生し，また，この転位 がバッファ表面へ伝播することを上位層が抑制することで, バッファ表面の結晶性が高く保たれていると考えられる。

薄化 3 層バッファは, $5 \mathrm{~nm}$ の極薄高 $\mathrm{Ge}$ 組成層を $\mathrm{Si}$ 基板 と薄化 2 層バッファ界面に挿入した構成からなる。ただし, 極薄の高 $\mathrm{Ge}$ 組成層(第 1 層) と薄化 2 層バッファ（第 2 層, 第 3 層）の間に極薄 $\mathrm{Si}$ 層（5 nm）を挿入し, 第 1 層の格子 欠陥が上位層に伝播しにくくした。下位界面の $\mathrm{Si}$ 基板と第 2 層間の格子不整合は $0.50 \%$ で第 2 , 第 3 層間の格子不整は $0.03 \%$ であった。下位界面の格子不整が基板と第 1 層間あ るいは第 1 層と第 2 層間のどちらに生じているかは明らか ではないが，下位界面に集中していることが判る。また， 格子不整合率の比較から薄化 3 層バッファの方が薄化 2 層 バッファより格子不整がより効果的に下位界面に集中して いることが判る。バッファ表面の緩和率も薄化 2 層バッフ アで $40 \%$, 薄化 3 層バッファで $50 \%$ と薄化 3 層バッファの

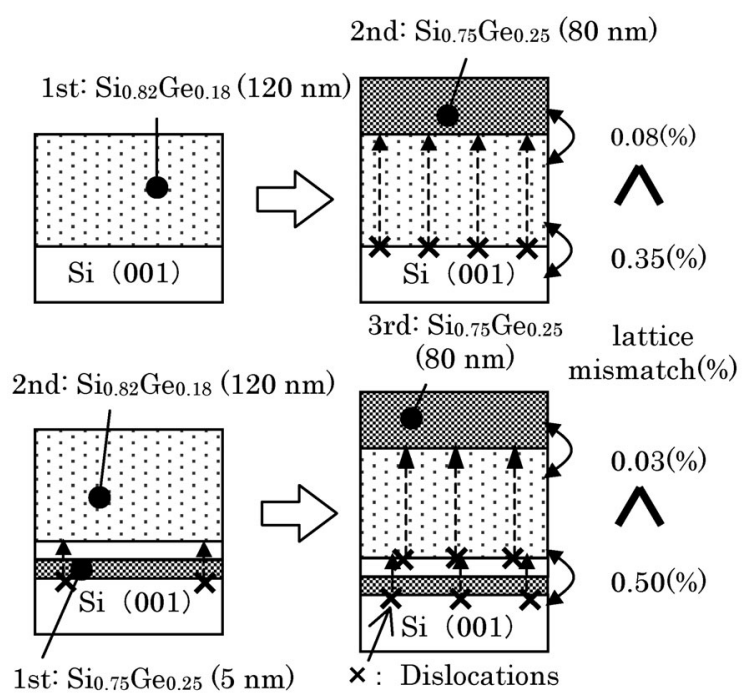

Fig. 1. Relaxation mechanisms of our previously proposed thin double- and triple-layer buffer.

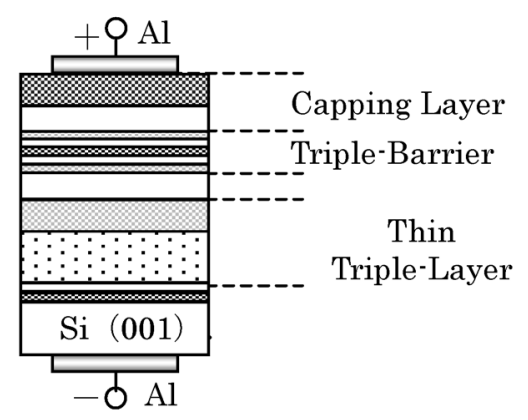

Fig. 2. Cross section of a RTD fabricated with the triple-layer buffer. 


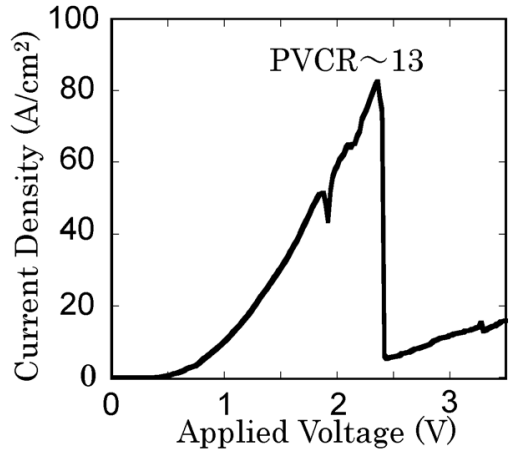

Fig. 3. Typical $I-V$ characteristics of a RTD fabricated with the triple-layer buffer.

方が $10 \%$ 上昇した。

この薄化 3 層バッファを用いて,第 2 層を $\mathrm{Si}_{0.82} \mathrm{Ge}_{0.18} 120$ $\mathrm{nm}$ ，第 3 層を $\mathrm{Si}_{0.75} \mathrm{Ge}_{0.25} 80 \mathrm{~nm}$ とし， RTD を作成した。 基板には 0.01 0.02 $\Omega \mathrm{cm} \mathrm{n}$ 型 $\mathrm{Si}$ (001) 用い，成膜中に はドーピングを行っていない。この RTD の構造を Fig. 2 に 示す。薄化 3 層バッファ上に $\mathrm{Si} 20 \mathrm{~nm}$ 形成後, 量子井戸部 として $\mathrm{Si}_{0.75} \mathrm{Ge}_{0.25} 3 \mathrm{~nm}$ (障壁) $/ \mathrm{Si} 3 \mathrm{~nm}$ (井戸) $/ \mathrm{Si}_{0.75} \mathrm{Ge}_{0.25}$ $3 \mathrm{~nm}$ (障壁) $/ \mathrm{Si} 5 \mathrm{~nm}$ (井戸) $/ \mathrm{Si}_{0.75} \mathrm{Ge}_{0.25} 3 \mathrm{~nm}$ (障壁)を形 成した。その後, キャップ層として $\mathrm{Si}_{0.75} \mathrm{Ge} 0.2535 \mathrm{~nm} / \mathrm{Si} 30$ $\mathrm{nm}$ を成長させた。また，電極として $\mathrm{Al}$ をそれぞれ形成し た。この RTD の $I$ - $V$ 特性を Fig. 3 に示す。室温下で PVCR 〜13 といら実用的な PVCR を得ることができた。このこと から, 形成した量子井戸が十分機能し, 非弾性散乱一の影 響の少ない結晶性の良いバッファを得ることができたと考 えられる。

〈3.2〉 P ドープ薄化 4 層バッファ $\quad$ RTD $の$ 電流密度 を向上するため, バッファおよびキャップ層成長時に $\mathrm{PH}_{3}$ を導入することでn 型ドーピングを施した。Fig. 2，3 で用 いた薄化 3 層バッファのドープ前後の SEM 像を Fig. 4 に 示す。

ドーピングを施したバッファ表面に無数の貫通転位が観 測され，また表面に凹凸が増大したことから，バッファ表 面の結晶性，および平坦性が悪化したことがわかる。これ は高濃度 $\mathrm{P}$ ドープにより $\mathrm{SiGe}$ 結晶内の格子間ポテンシャル が乱れたことにより，SiGe 層の緩和成長で貫通転位が顕著 になったためと考えられる。

そこで, これらの問題を解決し, 結晶性および平坦性の 向上を図るため, SiGe 層を 4 層にし, 発生する不整合転位 を分散したバッファを提案した。すなわち，従来の 2 層バ ッファの歪緩和機構である, 上層形成で下位層を歪緩和寸 ると共に，下位層からの転位伝播を抑制することにより表 面の結晶性を維持する歪緩和機構を利用して, 従来の薄化 2 層バッファより $\mathrm{Ge}$ 組成を細かく段階的に上昇することによ り複数の下位界面に転位を分散し，さらに，その転位の上 位層への表出を抑制することで, $\mathrm{P}$ ドープ時のバッファ表面 の結晶性および平坦性向上を試みた。また, 成膜温度をこ れまでの $630^{\circ} \mathrm{C}$ から $600^{\circ} \mathrm{C}$ 一低温化して熱エネルギーを小さ

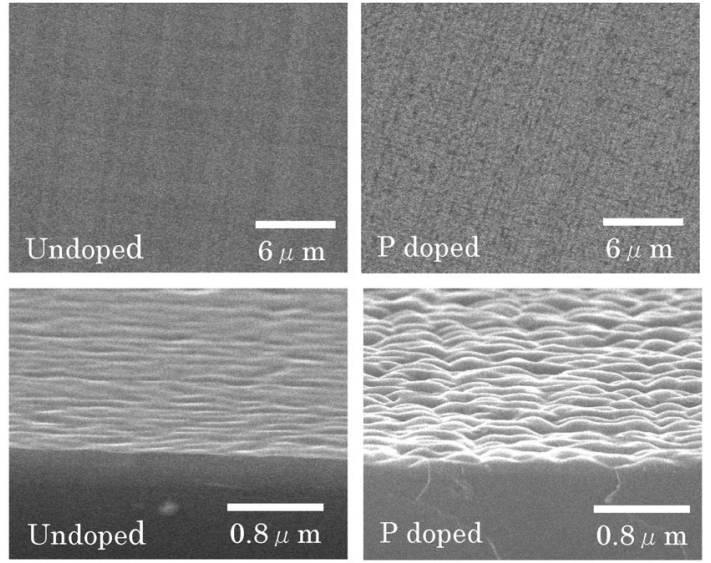

Fig. 4. Typical SEM images of triple-layer buffer surfaces without $\mathrm{P}$ doping (left) and with $\mathrm{P}$ doping (right).

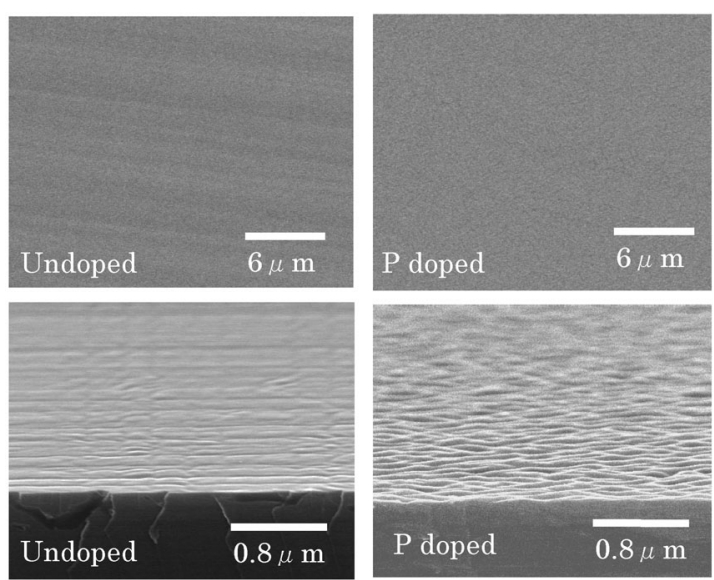

Fig. 5. Typical SEM images of quadruple-layer buffer surfaces without $\mathrm{P}$ doping (left) and with $\mathrm{P}$ doping (right).

くすることにより, 結晶内転位の発生および上位層への転 位伝播の抑制を図った。

薄化 4 層バッファの構造は $\mathrm{n}$ 型 $0.01 \sim 0.02 \Omega \mathrm{cm} \mathrm{Si}(001)$ 基板上にまず $\mathrm{P}$ ドープ量 $5 \times 10^{18} \mathrm{~cm}^{-3}$ の $\mathrm{Si}$ 層を $30 \mathrm{~nm}$ 成

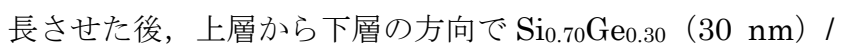
$\mathrm{Si}_{0.75} \mathrm{Ge}_{0.25}(80 \mathrm{~nm}) / \mathrm{Si}_{0.82} \mathrm{Ge}_{0.18}(30 \mathrm{~nm}) / \mathrm{Si}_{0.87} \mathrm{Ge}_{0.12}(100$ $\mathrm{nm})$ とした。第 1 層と第 2 層の臨界膜厚に対する厚みの割 合は $20 \pm 5 \%$ で, 第 1 層の厚みの割合を大きくした。第 1 層, 第 2 層はコヒーレントに成長するが, 第 3 層を成長したと きに臨界応力を超えて基板と第 1 層間, および第 1 層と第 2 層間に転位が発生するように設計した。この層構造を Fig. 6 に示す。また, 各 SiGe 層の P ドープ量はおよそ $2 \times 10^{19} \mathrm{~cm}^{-3}$ である。P ドープを施した場合と施さなかった場合の 4 層 バッファの SEM 像を Fig. 5 に示す。

Fig. 5 の $\mathrm{P}$ ドープを施さなかった 4 層バッファは $\mathrm{P}$ ドー プを施さなかった 3 層バッファと同様に高い平坦性と結晶 性を示した。Fig. 5 の P ドープを施した 4 層バッファ表面 は, 久陥構造が無くなり, 表面のう㸚りも低減し, ドープ 
を施さないバッファと比較して同様の結晶性を示した。 $\mathrm{P}$ ドープ 4 層バッファの貫通転位密度は $2 \times 10^{5} \mathrm{~cm}^{-2}$ とドープ を施さない 3 層バッファと同程度であった。

$\mathrm{P}$ ドープを施した 4 層バッファの各層成長後の SEM 像を Fig. 7 に示す。第 1 層，第 2 層成長時は緩和が無くコヒー レントに成長した。成長表面も十分に高い結晶性を示した （Fig. 7 (a)，(b))。 $\mathrm{Si}_{0.75} \mathrm{Ge}_{0.25}$ 第 3 層を成長すると歪緩和 が生じた。この時, $\mathrm{Si}$ 基板と $\mathrm{Si}_{0.88} \mathrm{Ge}_{0.12}$ 第 1 層との格子不 整合率は $0.15 \%$ に対し，Si0.88Ge0.12 第 1 層と Si $0.75 \mathrm{Ge} 0.25$ 第 3 層との格子不整合率は $0.30 \%$ と上位界面の側の格子不整 合率が大きく転位が上位界面により多く発生している結果 が得られた。しかし, 表面の平坦性は高く貫通転位の上昇 は見られなかった（Fig. 7 (c)）。一方，第 2 層は薄く XRD のスペクトルを測定できないため，第 1 層と第 2 層との格 子不整合率は測定できない。しかし，第 3 層形成後の緩和 で表面結晶性に悪化が見られないため，第 1 層と第 3 層間 に生じた格子不整合は，主に第 1 層と第 2 層間に格子不整 合転位が生じて緩和したために生じたと考えることができ る。したがって，2つの下位界面に分散して転位が発生し， かつ第 3 層が貫通転位の伝播を抑制したと考えられる。こ のとき, $\mathrm{Si}_{0.88} \mathrm{Ge}_{0.12}$ 第 1 層は $27 \%, \mathrm{Si}_{0.75} \mathrm{Ge}_{0.25}$ 第 3 層は $43 \%$ 歪緩和した。

さらに上層の $\mathrm{Si}_{0.70} \mathrm{Ge}_{0.30}$ 第 4 層層を成長させると

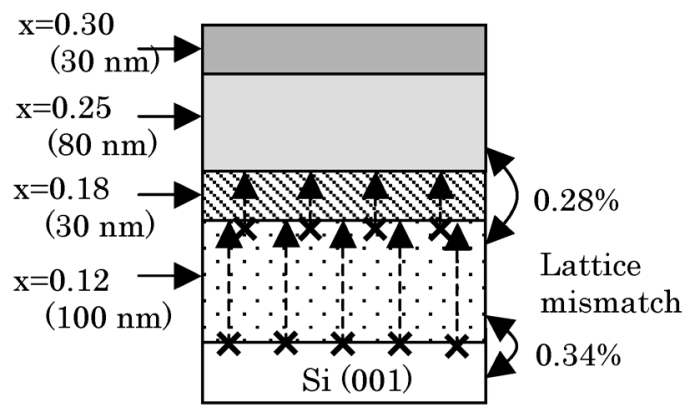

Fig. 6. Structure of a quadruple-layer buffer doped with $\mathrm{P}$ and obtained lattice mismatches.

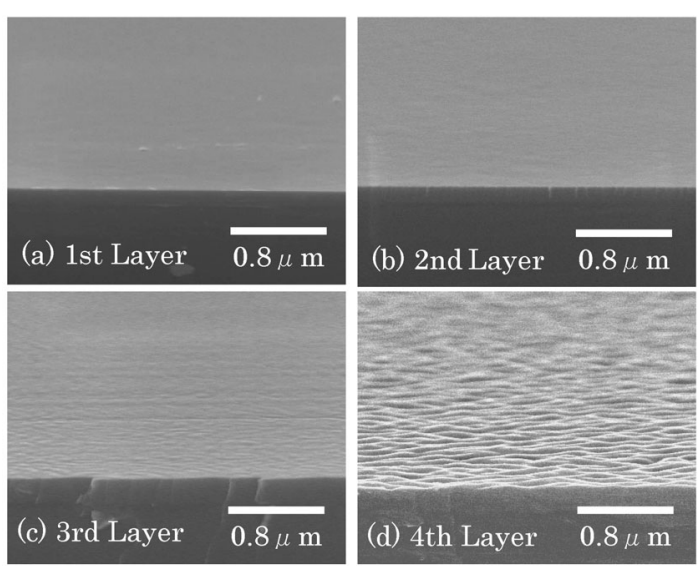

Fig. 7. Each layer's surface SEM image of the P-doped quadruple-layer buffer.
$\mathrm{Si}_{0.88} \mathrm{Ge}_{0.12}$ 第 1 層は $66 \%$ と大きく歪緩和し, また, $\mathrm{Si}_{0.75} \mathrm{Ge}_{0.25}$ 第 3 層は $59 \%$ 緩和した。また, 格子不整合率は $\mathrm{Si}$ 基板と $\mathrm{Si}_{0.88} \mathrm{Ge}_{0.12}$ 第 1 層間で $0.34 \%, \mathrm{Si}_{0.88} \mathrm{Ge}_{0.12}$ 第 1 層と $\mathrm{Si} 0.75 \mathrm{Ge} 0.25$ 第 3 層閒で $0.28 \%$ となり, 最下位の界面の格子 不整合が大きく増大したことから（Fig. 6)，主にこの界面 で転位が増加したと考えられる。薄化 4 層バッファではド ーピングを施しているにもかかわらず，その $\mathrm{Si}_{0.75} \mathrm{Ge}_{0.25}$ 第 3 層は, 同じ組成比の薄化 3 層バッファの $\mathrm{Si}_{0.75} \mathrm{Ge}_{0.25}$ 最上 層の緩和率 $50 \%$ をまわる歪緩和を示した。また，表面の うねりは増大したが, 貫通転位の増大は見られなかった(Fig. 7 (d))。

このように，第 3 層，第 4 層は，基板と第 1 層間および 第 1 層と第 2 層間の転位発生の駆動力となると同時に, 転 位伝播を抑制する機能を示すことが判った。また，複数の 下位界面に転位の発生を分散したため, 転位の表面への表 出を抑制し, 高い結晶性のバッファ表面を得ることが難し かった P ドープした歪緩和バッファの作成に極めて有効で あることが判った。

〈3.3〉 P ドープ 4 層バッファを用いたRTD の I-V 特性 作成した 4 層バッファ上に i-Si $7 \mathrm{~nm} / \mathrm{n}$-Si $7 \mathrm{~nm}$ 形成後, 量子井戸部として i-Si ${ }_{0.70} \mathrm{Ge}_{0.30} 1.5 \mathrm{~nm}$ (障壁) /i-Si $5 \mathrm{~nm}$ (井

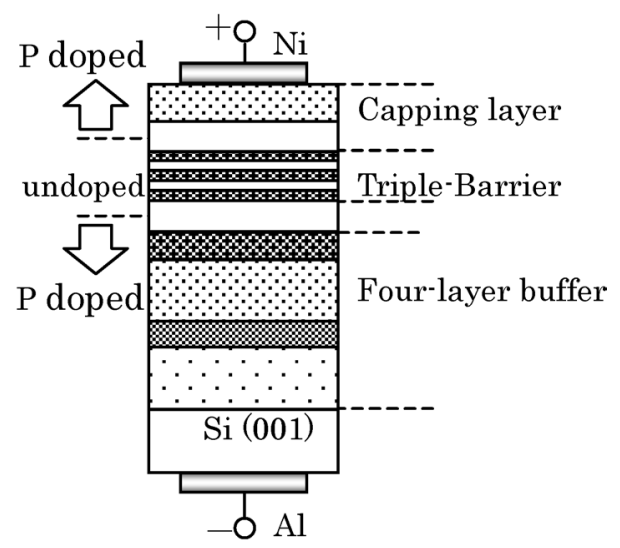

Fig. 8. Structure of a RTD fabricated with the P-doped quadruple-layer buffer.

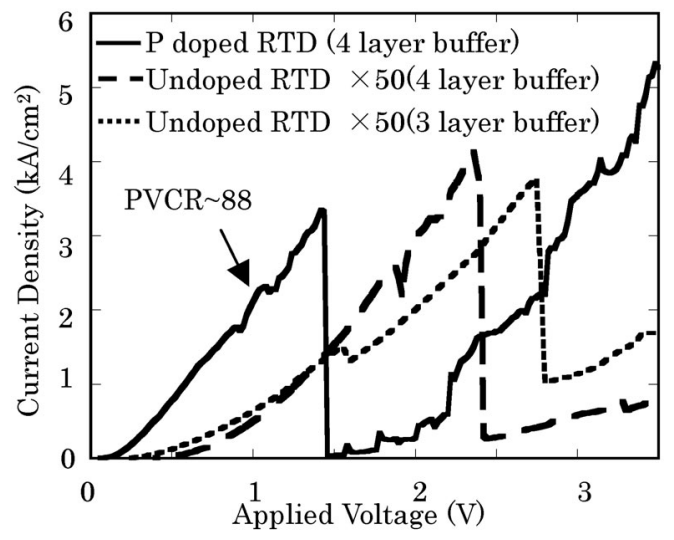

Fig. 9. Comparison between $I-V$ characteristics of RTDs fabricated with the P-doped quadruple-layer buffer and undoped buffers. 


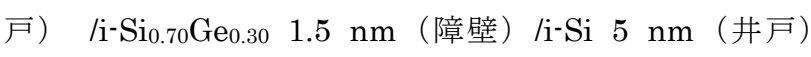
/i-Si ${ }_{0.70} \mathrm{Ge}_{0.30} 1.5 \mathrm{~nm}$ (障壁) を成長させた。その後, キ ヤップ層としてn-Si ${ }_{075} \mathrm{Ge}_{0.25} 30 \mathrm{~nm} / \mathrm{n}-\mathrm{Si} 7 \mathrm{~nm} / \mathrm{i}-\mathrm{Si} 7 \mathrm{~nm}$ を 成長させた。また, 電極として $\mathrm{Ni}$ を真空蒸着法で形成し, $\phi 50 \mu \mathrm{m}$ の円形の Ni 電極をマスクとしてメサ形構造を形 成した。その後, $\mathrm{Si}$ 基板裏面に $\mathrm{Al}$ 電極を作成し, RTD の $I$ - $V$ 特性を測定した。同様の構造をアンドープの条件でも作 成した。この RTD の構造を Fig. 8 に， $I-V$ 特性測定の結果 を図 9 に示す。

これらの素子に含まれる貫通転位は 4 個程度と見積もら れ, 動特性の得られたIII-V系 RTD について報告されてい る 30 個(1)より十分少ないことが判る。Fig. 9 の測定結果に 示すように, P ドープ 4 層バッファを用いた RTD の PVCR として,〜88の高い数值を得た。この RTD は, SiGe 障壁 の高さが，第 3 層の歪緩和率を基に $80 \mathrm{meV}$ 程度と見積も られるが，十分な負性抵抗特性を示していることが判る。 さらに, $\mathrm{P}$ ドープ 4 層バッファを用いた RTD では, 電流密 度がアンドープの薄化 3,4 層バッファを用いた RTD と比 ベ50 倍程度増加し, 高電流密度化に成功したことが判る。 アンドープの RTD に比べ高い電流密度であるにもかかわら ず，共鳴トンネルが起こる電圧はドーピングによりおよそ 半分程度になったことから, バッファ部, キャップ部の抵 抗が下がり, これらの層での電圧降下が減少したと考える ことができる。

\section{4. まとめ}

我々が提案した薄化 3 層バッファを用いた RTD の高電流 密度化を目指し, 従来アンドープであった $\mathrm{SiGe}$ バッファ層 に $\mathrm{P}$ ドープによる $\mathrm{n}$ 型ドーピングを試みた。しかし，ドー ピングにより薄化 3 層バッファの結晶性および平坦性は悪 化した。そこで先に提案した薄化 2 層, 3 層バッファの歪緩 和機構を基に, 各界面に転位を分散し高いバッファ表面結 晶性および平坦性を持つ $\mathrm{P}$ ドープ 4 層バッファを提案した。 この 4 層バッファでは主に転位が基板と第 1 層間および第 1 層と第 2 層間に発生し，第 3 層および第 4 層は転位発生の 駆動力および転位の表面伝播の抑制として働くという結果 が得られた。このバッファを用いて高電流密度 $\left(3.4 \mathrm{kAcm}^{-2}\right)$ と大きな PVCR（〜88）を有する RTD が試作できた。

\section{謝辞}

本研究の一部は, 東京農工大学 21 世紀 COE “ナノ未来 材料”プログラムの援助により行われた。

(平成 18 年 2 月 9 日受付)

\section{文献}

(1) J. R. Shöderström, E. R. Brown, C. D. Parker, L. J. Mahoney, J. Y. Yao, T. G. Anderson, and T. C. Mcgill : "Growth and characterization of high current density, high-speed InAs/AlSb resonant tunneling diodes", Appl. Phys. Lett., Vol.58, p.275 (1991)
(2) E. R. Brown, J. R. Shöderström, C. D. Parker, L. J. Mahoney, K. M. Molvar, and T. C. Mcgill : "Oscillation up to $712 \mathrm{GHz}$ in InAs/AlSb resonant-tunneling diodes”, Appl. Phys. Lett., Vol.58, p.2291 (1991)

(3) D. J. Paul, I. V. Zozoulenko, K. -F. Berggren, B. Holländer, S. Mantl, N. Griffin, B. P. Coonan, G. Redmond, and G. M. Crean : "n-type Si/SiGe resonant tunneling diodes", Materials Science and Engineering B, Vol.89, p.26 (2002)

(4) Z. Matutionovic-Krstelj, C. W. Liu, X. Xiao, and J. C. Sturm : "Symmetric $\mathrm{Si} / \mathrm{Si}_{1 \times \mathrm{x}} \mathrm{Ge}_{\mathrm{x}}$ electron resonant tunneling diodes with an anomalous temperature behavior", Appl. Phys. Lett., Vol.62, p.603 (1993)

(5) Y. Suda and H. Koyama : "Electron resonant tunneling with a high peak-to-vally ratio at room temperature in $\mathrm{Si}_{1 \cdot \mathrm{x}} \mathrm{Ge}_{\mathrm{x}} / \mathrm{Si}$ triple barrier diodes", Appl. Phys. Lett., Vol.79, p.2273 (2001)

(6) J. W. P. Hsu, E. A. Fitzgerald, Y. H. Xie, P. J. Silverman, and M. J. Cardillo, "Surface morphology of related $\mathrm{Ge}_{x} \mathrm{Si}_{1 \cdot \mathrm{x}}$ films", Appl. Phys. Lett., $\underline{61}, 1293$ (1992).

(7) Y. Suda : " $\mathrm{Si}_{1 \cdot \mathrm{x}} \mathrm{Ge}_{\mathrm{x}} / \mathrm{Si}$ triple-barrier RTD with a high peak-to-valley ratio of $\geqq 180$ at RT", ECS Proc. Volume on Advanced Luminescent Materials and Quantum Confinement II, ed. by M. Cahay et al., PV2002-9 (The Electrochemical Society Inc., NJ, p.47 (2002)

(8) H. Maekawa, M. Shoji, and Y. Suda : "High PVCR Si/Si $1_{1 \times} G_{\text {Ge }}$ DW RTD formed with new triple-layer buffer", Materials Science in semiconductor Processing, Vol.8, p.417 (2005)

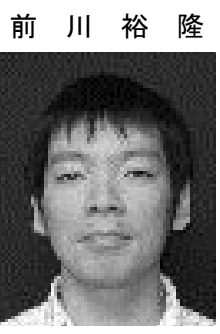

（非会員） 2002 年 3 月東京農工大学工学部卒。 2004 年東京農工大学大学院工学研究科博士前 期課程卒。現在, 東京農工大学大学院工学教育 部博士後期課程在籍。東京農工大学 21 世紀 COE”ナノ未来材料”プログラム RA。
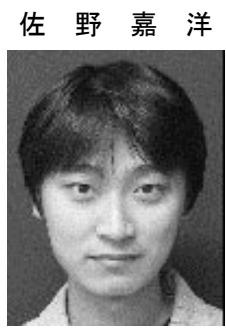

上野千 尋

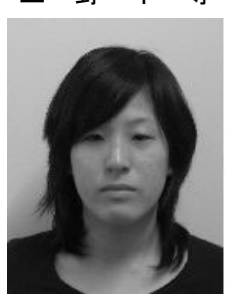

（非会員） 2005 年 3 月東京農工大学工学部卒。 現在, 東京農工大学大学院工学教育部博士前期 課程在籍。

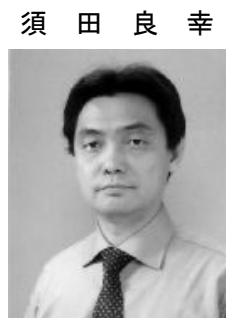

（非会員）現在，東京農工大学工学部在籍。

（正員） 1981 年 3 月東北大学大学院博士後期 課程卒。現在, 東京農工大学総合情報メディア センター。大学院共生科学技術研究部および大 学院工学教育部兼務。 